\title{
BURNOS HIGIENISTŲ POŽIŪRIS I MOTYVACINIO INTERVIU TAIKYMĄ DIRBANT SU PACIENTU
}

\author{
Liveta Bliūdžiūtė, Rasa Tamulienè, Daiva Mačiulienė \\ Kauno kolegija
}

Raktažodžiai: motyvacinis interviu, burnos higienistas.

\section{Santrauka}

Tyrimo tikslas - atskleisti burnos higienistų požiūrị į motyvacinio interviu taikymą dirbant su pacientu. Tyrime dalyvavo 71 burnos higienistas. Duomenų rinkimo metodas - apklausa internetu. Tyrimo metu surinktų duomenu analizė atlikta taikant aprašomosios statistikos bei grupiu lyginimo metodus. Atlikto tyrimo rezultatai atskleide, kad motyvacinio interviu taikymas nesiskiria privačiose ir valstybinėse gydymo ịstaigose, burnos higienistai, turintys didesnị nei penkerių metų darbo stažą yra linkę motyvacinį interviu dažniau taikyti savo profesinejje praktikoje. Dažniausi veiksniai, lemiantys burnos higienisto apsisprendimą taikyti motyvacinį interviu, yra paciento burnos ertmès būklè bei paciento žinios apie burnos ertmès priežiūrą. Tyrimo rezultatai atskleidè burnos higienistų nuomonę, kad pacientams labiausiai trūksta motyvacijos valyti tarpdančius ir liežuvị, atsisakant ilgalaikių blogų ịpročių, bei profilaktiniam apsilankymui pas burnos priežiūros specialistą. Didžioji dalis tyrime dalyvavusių burnos higienistų mano, kad motyvacinis interviu turètų būti ịtrauktas ị reguliarią pacientų priežiūrą odontologijos kabinete, daugelio lètinių burnos ligų galima išvengti, naudojant motyvacinị interviu. Burnos higienistų nuomone, specialistas turi suprasti paciento perspektyvą, jo mintis ir jausmus, nevertindamas, nekritikuodamas, neprieštaraudamas. Pacientas turi būti ịtikintas, kad ịmanoma pakeisti su burnos sveikata susijusią elgseną ir sumažinti su tuo susijusias problemas. Trečdalis tyrime dalyvavusių burnos higienistų nurodè, jog jie nèra tikri, ar motyvacinis interviu yra efektyvesnis, nei burnos ertmès priežiūros instruktažas.

\section{İvadas}

Motyvacinis interviu (MI) - tai ị pacientą orientuotas konsultavimo stilius, kuris padeda pacientams išanalizuoti ir išspręsti tam tikrą problemą, didinant motyvaciją keisti su sveikata susijusią elgseną [1]. Epidemiologiniai duomenys rodo, kad rūkymas, alkoholio ir narkotikų vartojimas, nesveika mityba bei nepakankamas fizinis aktyvumas yra susijęs su padidejusiu sergamumu ir mirtingumu. Pažymima, kad netinkamo su sveikata susijusio elgesio sukeltų ligų gydymas reikalauja gerokai daugiau finansinių išlaidų nei investicijos i profilaktiką [5].

Mokslinių šaltinių $[2,4,5,10,11]$ apžvalga rodo, kad motyvacinis interviu plačiai taikomas siekiant padeti pacientams atsisakyti žalingų ịpročių (rūkymas, alkoholio ir narkotikų vartojimas), didinti fizini aktyvumą, diabeto kontrolei, valgymo sutrikimams, svorio kontrolei, burnos ertmès priežiūrai gerinti. Tyrimai [7-9] atskleidè, jog motyvacinio interviu taikymas burnos sveikatos srityje gali būti efektyvi priemonè, leidžianti padèti pacientui pakeisti netinkamą su burnos sveikata susijusią elgseną. Pastebima, kad laikytis burnos ertmès priežiūros rekomendacijų nėra sunku, tačiau žmonèms trūksta noro ir motyvacijos prižiūrèti savo burnos ertmę. Nustatyta, kad nuo 30 iki 60 proc. suteiktos informacijos pamirštama per 1 valandą, o 50 proc. rekomendacijų nesilaikoma [12]. Nors paplitęs įsitikinimas, jog pakanka pacientų švietimo apie neigiamas elgesio pasekmes [3], tyrimai [6] atskleidè, kad keičiant su burnos sveikata susijusią elgseną, motyvacinis interviu yra veiksmingesnis nei ịprastiniai sveikatos ugdymo metodai ar tiesiog paciento instruktavimas apie burnos ertmès priežiūrą.

Mokslinès literatūros analizė parodè [2,3,7-9], jog didžiojoje dalyje burnos sveikatos tyrimų yra vertinamas motyvacinio interviu taikymo efektyvumas, siekiant keisti paciento su burnos sveikata susijusią elgseną, tačiau neaišku, koks yra pačiu burnos priežiūros specialistų požiūris ị motyvacinio interviu naudojimą jų profesineje veikloje.

Tyrimo tikslas - atskleisti burnos higienistu požiūrị ị motyvacinio interviu taikymą, dirbant su pacientu. Tyrimo problema - koks burnos higienistų požiūris ị motyvacinio interviu taikymą, dirbant su pacientu? Tyrimo objektas burnos higienistų požiūris ị motyvacinio interviu taikymą, dirbant su pacientu. 
Tyrimo medžiaga ir metodai

Tyrimo organizavimas, eiga, etika ir imties sudarymo principai. Tyrimas vyko 2021 metų kovo-balandžio mènesiais. Kvietimu dalyvauti tyrime su nuorodomis ị klausimyną buvo dalijamasi per burnos priežiūros specialistus vienijančias socialinių tinklų grupes. Imties sudarymo principas netikimybinè proginè. Atliekant tyrimą, buvo laikomasi informuoto sutikimo ir laisvo apsisprendimo dalyvauti tyrime etikos principų.

Tyrimo instrumentas, duomenų rinkimo ir analizès metodai. Tyrimo metu naudotas duomenų rinkimo metodas - apklausa internetu. Klausimyną sudarè 17 klausimų, apimančių keturis klausimų blokus: motyvacinio interviu taikymo aplinkybès, burnos higienistų požiūris ị motyvacinio interviu efektyvumą, paciento motyvavimas bei tyrimo dalyvių charakteristikos. Naudoti duomenų analizès metodai: aprašomosios statistikos skaičiavimai (dažniai) ir grupių palyginimas (Kruskal Wallis kriterijus).

Tyrimo dalyviai. Tyrime dalyvavo 71 burnos higienistas, iš kurių didžiają dalị sudarè moterys (1 lentelè). Didžioji dalis (63,38\%) tyrime dalyvavusių burnos higienistų dirba privačiose odontologijos istaigose ir turi iki penkerių metų darbo stažą (1 lentelè).

\section{Tyrimo rezultatai}

Tyrimo rezultatai atskleide, kad didžioji dalis $(71,8 \%)$ tyrime dalyvavusių burnos higienistų žino, kas yra motyvacinis interviu. Nustatyta, jog 60,8 proc. tyrimo dalyvių, žinančių, kas yra motyvacinis interviu, ji taiko savo profesineje veikloje, 23,5 proc. tiriamujų - netaiko, kiti $(15,7$ \%) nèra tikri, ar jų taikoma pacientų motyvavimo technika yra motyvacinis interviu (2 lentelè).
1 lentelè. Tyrimo dalyvių pasiskirstymas pagal lytị, darbo stažą ir ịstaigos tipą $(\mathrm{N}=71)$.

\begin{tabular}{|l|c|c|c|c|}
\hline Darbo stažas & Valstybinė & Privati & $\begin{array}{c}\text { Valstybinė ir } \\
\text { privati }\end{array}$ & N (moterys/vyrai) \\
\hline Iki 5 metų & $31,0 \%(13)$ & $54,8 \%(23)$ & $14,2 \%(6)$ & $\mathbf{4 2}(\mathbf{3 8} / \mathbf{4})$ \\
Nuo 5 iki 10 metų & $15,0 \%(3)$ & $70 \%(14)$ & $15,0 \%(3)$ & $\mathbf{2 0}(\mathbf{1 8} / \mathbf{2})$ \\
Nuo 11iki 20 metu & $14,3 \%(1)$ & $85,7 \%(6)$ & $0 \%(0)$ & $7(6 / 1)$ \\
Nuo 21 iki 30 metų & $0 \%(0)$ & $100 \%(2)$ & $0 \%(0)$ & $\mathbf{2 ( 2 / 0 )}$ \\
Daugiau nei 30 metų & $0 \%(0)$ & $0 \%(0)$ & $0 \%(0)$ & $\mathbf{0}(\mathbf{0} / \mathbf{0})$ \\
Iš viso: & $\mathbf{2 3 , 9 4 \% ( 1 7 )}$ & $\mathbf{6 3 , 3 8 \% ( 4 5 )}$ & $\mathbf{1 2 , 6 8 \% ( 9 )}$ & $\mathbf{7 1 ( 6 4 / 7 )}$ \\
\hline
\end{tabular}

2 lentelè. Burnos higienistų žinios apie motyvacinį interviu bei jo taikymas praktikoje $(N=71)$.

\begin{tabular}{|c|c|c|c|}
\hline \multirow{2}{*}{\multicolumn{2}{|c|}{$\begin{array}{l}\text { Burnos higienistų žinios apie MI ir jo tai- } \\
\text { kymas }\end{array}$}} & \multicolumn{2}{|c|}{ Žinios apie MI } \\
\hline & & \multirow{2}{*}{$\begin{array}{c}\text { žino } \\
60,8 \%(31) \\
\end{array}$} & \multirow{2}{*}{$\begin{array}{l}\text { nežino } \\
0 \%(0)\end{array}$} \\
\hline Taikymas profe- & taiko & & \\
\hline sinëje veikloje & netaiko & $23,5 \%(12)$ & $0 \%(0)$ \\
\hline & nèra tikras & $15,7 \%(8)$ & $0 \%(0)$ \\
\hline \multicolumn{2}{|l|}{ Iš viso: } & $71,8 \%(51)$ & $28,2 \%(20)$ \\
\hline
\end{tabular}

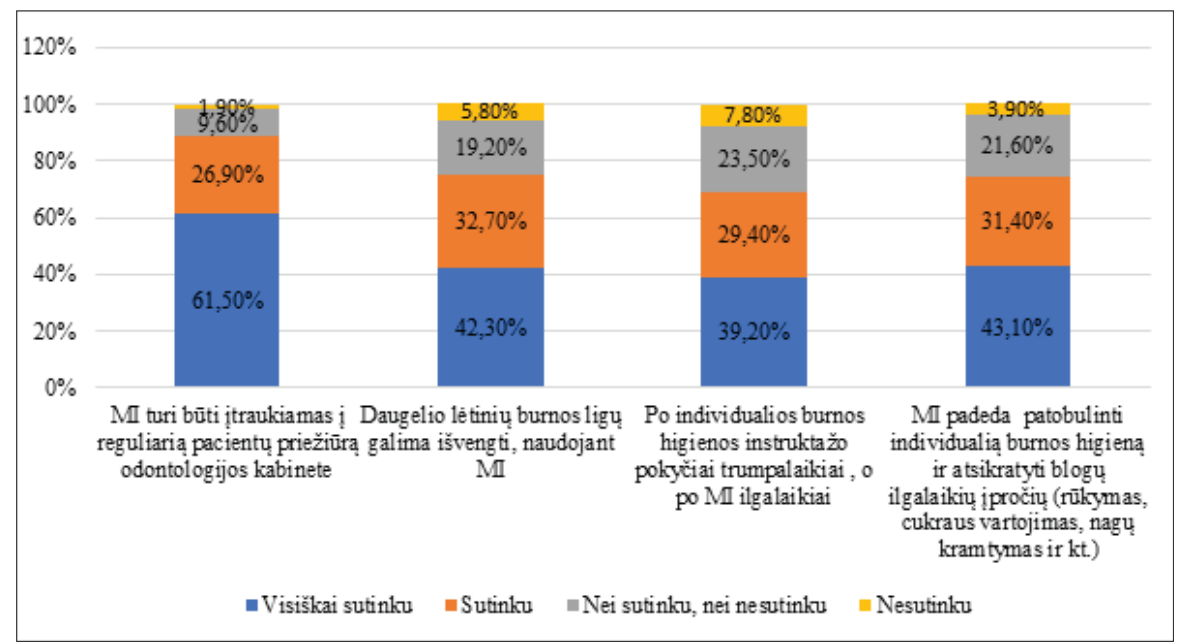

1 pav. Burnos higienistų požiūris ị motyvacinio interviu taikymą $(\mathrm{N}=51)$

3 lentelè. Motyvacinio interviu taikymas priklausomai nuo įstaigos tipo ir darbo stažo $(\mathrm{N}=51)$.

\begin{tabular}{|c|c|c|c|c|c|c|}
\hline \multicolumn{2}{|c|}{$\begin{array}{l}\text { Motyvacinio interviu taiky- } \\
\text { mas }\end{array}$} & $\mathbf{N}$ & $\begin{array}{l}\text { Laisvès } \\
\text { laipsniai }\end{array}$ & $\begin{array}{c}\text { Vidutinis } \\
\text { rangas }\end{array}$ & $\begin{array}{l}\text { Kruskal- } \\
\text { Wallis H }\end{array}$ & p \\
\hline \multirow{3}{*}{$\begin{array}{l}\text { Istaigos, ku- } \\
\text { rioje dirbama, } \\
\text { tipas }\end{array}$} & valstybinè & 14 & \multirow{3}{*}{2} & 30,43 & \multirow[t]{3}{*}{2,980} & \multirow[t]{3}{*}{0,225} \\
\hline & privati & 30 & & 23,45 & & \\
\hline & $\begin{array}{l}\text { valstybine ir } \\
\text { privati }\end{array}$ & 7 & & 28,07 & & \\
\hline \multirow[t]{3}{*}{ Darbo stažas } & iki 5 metų & 29 & \multirow[t]{3}{*}{2} & 31,36 & \multirow[t]{3}{*}{11,586} & \multirow[t]{3}{*}{0.003} \\
\hline & $\begin{array}{l}\text { nuo } 5 \text { iki } 10 \\
\text { metų }\end{array}$ & 17 & & 18,53 & & \\
\hline & $\begin{array}{l}\text { nuo } 11 \text { iki } 20 \\
\text { metų }\end{array}$ & 5 & & 20,30 & & \\
\hline
\end{tabular}


Didžioji dalis tyrime dalyvavusių burnos higienistų, bei nurodžiusiuju, jog žino, kas yra motyvacinis interviu, pritare teiginiams, jog „motyvacinis interviu turètų būti ịtrauktas ị reguliarią pacientų priežiūrą odontologijos kabinete" (visiškai sutiko su tei-

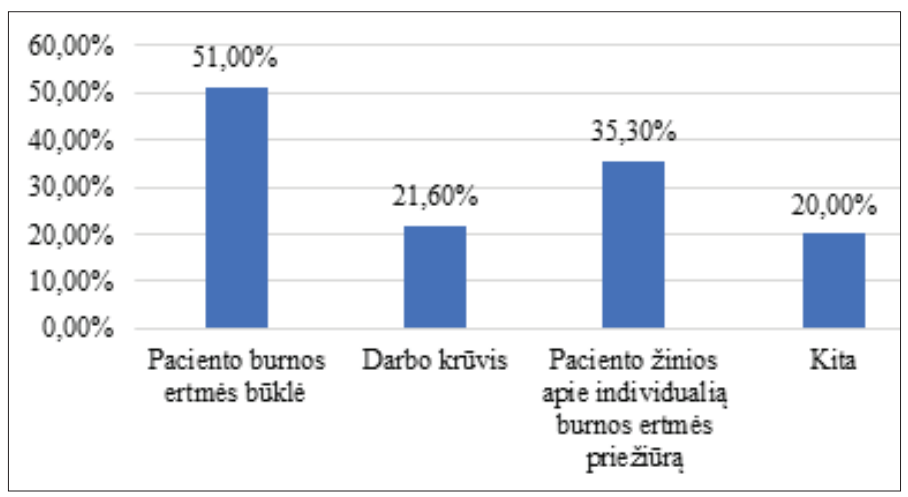

2 pav. Veiksniai, lemiantys burnos higienisto apsisprendimą taikyti motyvacini interviu $(\mathrm{N}=51)$

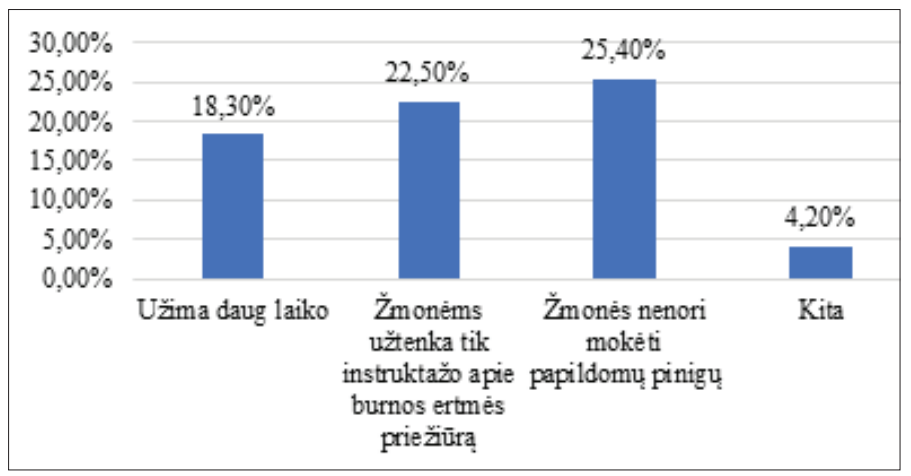

3 pav. Priežastys, dèl kurių burnos higienistai netaiko motyvacinio interviu $(\mathrm{N}=51)$

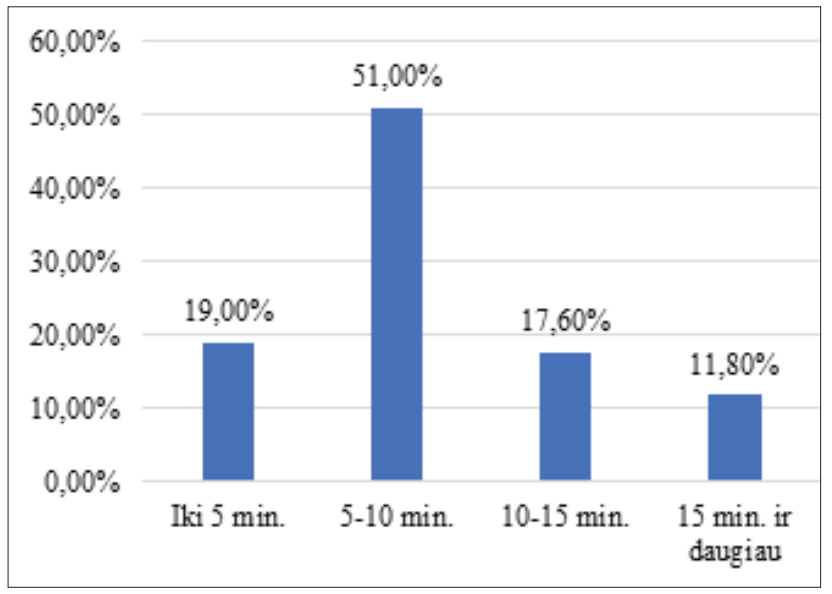

4 pav. Vidutinis laikas per dieną, skiriamas motyvuoti vieną pacientą prižiūrèti burnos ertmę $(\mathrm{N}=51)$ giniu $-61,50 \%$, sutiko - 29,60\%) ir ,daugelio lètinių burnos ligų galima išvengti, naudojant motyvacini interviu“" (visiškai sutiko su teiginiu $-42,30 \%$, sutiko - 32,70 \%). Maždaug penktadalis tyrime dalyvavusių burnos higienistų išsakè neutralią poziciją, vertindami savo požiūrị ị teiginius ,,po individualios burnos higienos instruktažo išlieka trumpalaikiai pokyčiai, o po motyvacinio interviu - ilgalaikiai““ $(23,50 \%)$, bei „motyvacinis interviu ne tik padeda patobulinti individualią burnos higieną, tačiau ir atsikratyti blogų ipročių, tokių kaip rūkymas, cukraus vartojimas, nagų kramtymas ir pan.“ (21,60\%), (1 pav.).

Tyrimo metu surinktų duomenų analizè parodè, kad motyvacinio interviu taikymas statistiškai reikšmingai nesiskiria $(\mathrm{p}=0,225)$ tarp burnos higienistų, dirbančių valstybinėse, privačiose bei valstybinèse ir privačiose gydymo ịstaigose, tačiau aptiktas statistiškai reikšmingas skirtumas $(\mathrm{p}=0,003)$ tarp skirtingą darbo stažą turinčiu burnos higienistų (3 lentelè). Nustatyta, kad burnos higienistai, turintys 5-10 metų (vidutinis rangas - 18,53) ir 11-20 metų (vidutinis rangas - 20,30) darbo stažą, dirbdami su pacientu linkę dažniau taikyti motyvacinį interviu, nei burnos higienistai, turintys darbo stažą iki penkerių metų (vidutinis rangas - 31,36; mažesnis vidutinio rango skaičius rodo dažnesnị motyvacinio interviu taikymą) (3 lentelè). Burnos higienistų, turinčių didesnị nei 21 metų darbo stažą bei taikančiu motyvacinị interviu tiriamujjų grupèje nebuvo.

Nustatyta, jog dažniausias veiksnys, lemiantis burnos higienisto apsisprendimą taikyti motyvacinị interviu, yra paciento burnos ertmès būklè (51\%). 35,30 \% tyrimo dalyvių nurodè, kad jų apsisprendimą skirti motyvacinị interviu nulemia paciento žinios apie individualią burnos ertmès priežiūrą, 21,60\% - darbo krūvis (2 pav.).

Dažniausios priežastys, kodèl burnos higienistai, žinantys, kas yra motyvacinis interviu, nusprendžia jo netaikyti, yra šios: žmonès nenori mokèti papildomai pinigų $(25,40 \%$ ), žmonẻms užtenka tik instruktažo apie burnos ertmès priežiūrą $(22,50 \%)$, užima daug laiko (18\%) (3 pav.).

51 proc. burnos higienistų, žinančių, kas yra motyvacinis interviu, nurodè, jog motyvuoti vieną pacientą prižiūrèti burnos ertmę per dieną jie skiria 5-10 minučių, 19 proc. - iki 5 min., 17,60 proc. - 10-15 min., 11,80 proc. - 15 min. ir daugiau. Vidutinè motyvacinio interviu trukmè yra 30 minučių, o trumpesnis paciento motyvavimas dažniausiai apima tik paciento instruktavimą apie burnos ertmès priežiūrą, kurio metu taikoma tik motyvacinio interviu technika, tačiau ne motyvacinis interviu. Gautieji tyrimo rezultatai rodo, kad nors didesnè dalis burnos higienistų žino, kas yra motyva- 
cinis interviu ir ji taiko savo profesineje veikloje (2 lentelè), vis dèlto tikraji motyvacinį interviu jie naudoja savo veikloje retai, nes tik $11,8 \%$ burnos higienistų nurode, kad paciento motyvavimui skiria ilgiau nei 15 minučių (4 pav.).

Didžioji dalis tyrime dalyvavusių burnos higienistų nurodè, kad pacientams labiausiai trūksta motyvacijos prižiūrèti tarpdančius $(92,2 \%)$, atsisakyti ilgalaikių blogu ịpročių (56,5\%), valyti liežuvị $(47,10 \%)$, lankytis profilaktiškai pas burnos priežiūros specialistą $(41,20 \%)$, (5 pav.).

Didžioji dalis tyrime dalyvavusių burnos higienistų buvo linkę pritarti teiginiams, jog ,pacientas turi būti ịtikintas, kad įmanoma pakeisti su burnos sveikata susijusią elgseną ir sumažinti su tuo susijusias problemas" (visiškai sutiko - 49\%, sutiko - 35,30\%), „burnos higienistas turi suprasti paciento perspektyvą, mintis ir jausmus nevertindamas, nekritikuodamas, neprieštaraudamas" (visiškai sutiko $62,70 \%$, sutiko - $25,50 \%$ ), ,motyvacinio interviu technikos taikymas padeda žmonèms pakeisti elgseną, ipročius ir taip pagerinti burnos sveikatos būklę" (visiškai sutiko $-47,10 \%$, sutiko - 39,20\%) (6 pav.).

37,20 proc. tyrime dalyvavusių burnos higienistų nei sutiko nei nesutiko su teiginiu, jog ,,individualios burnos higienos instruktažas yra mažiau efektyvus nei motyvacinis interviu“ (6 pav.). Tai rodo, kad nemaža dalis burnos higienistų, nepaisant to, jog visiškai sutinka ir sutinka su dauguma motyvacinio interviu technikų, vis dèlto nèra tikri dèl to, ar motyvacinis interviu yra efektyvesnis nei individualios burnos higienos instruktažas. Tai gali būti viena iš priežasčių, kodèl motyvacinis interviu burnos higienisto profesinejje veikloje yra sąlyginai retai taikomas (4 pav.).

\section{Išvados}

1. Tyrimo rezultatai atskleide, kad didžioji dalis tyrime dalyvavusių burnos higienistų žino, kas yra motyvacinis inter- viu. Nustatyta, kad daugiau nei pusė burnos higienistų, žinančių, kas yra motyvacinis interviu, jị taiko savo profesineje veikloje. Tyrimo rezultatai atskleidè, kad motyvacinio interviu taikymas nesiskiria privačiose ir valstybinèse gydymo ìstaigose, tačiau burnos higienistai, turintys didesnį nei penkerių metų darbo stažą yra linkę dažniau jį taikyti savo profesinejje veikloje. Dažniausi veiksniai, lemiantys burnos higienisto apsisprendimą taikyti motyvacinį interviu, yra paciento burnos ertmès būklè bei paciento žinios apie burnos ertmès priežiūrą.

2. Tyrimo rezultatai atskleidè, kad remiantis burnos higienistų nuomone, pacientams labiausiai trūksta motyvacijos valyti tarpdančius ir liežuvị, atsisakant ilgalaikių blogų ịpročių bei profilaktinių apsilankymų pas burnos priežiūros specialistą. Didžioji dalis tyrime dalyvavusių burnos higienistų mano, kad motyvacinis interviu turètų būti ịtrauktas ị reguliarią pacientų priežiūrą odontologijos kabinete, daugelio lètinių burnos ligų galima išvengti, naudojant motyvacinị interviu. Tyrimo dalyvių nuomone, pacientas turi būti įtikintas, kad įmanoma pakeisti su burnos sveikata susijusią elgseną ir sumažinti su tuo susijusias problemas, burnos higienistas turi suprasti paciento perspektyvą, mintis ir jaus-

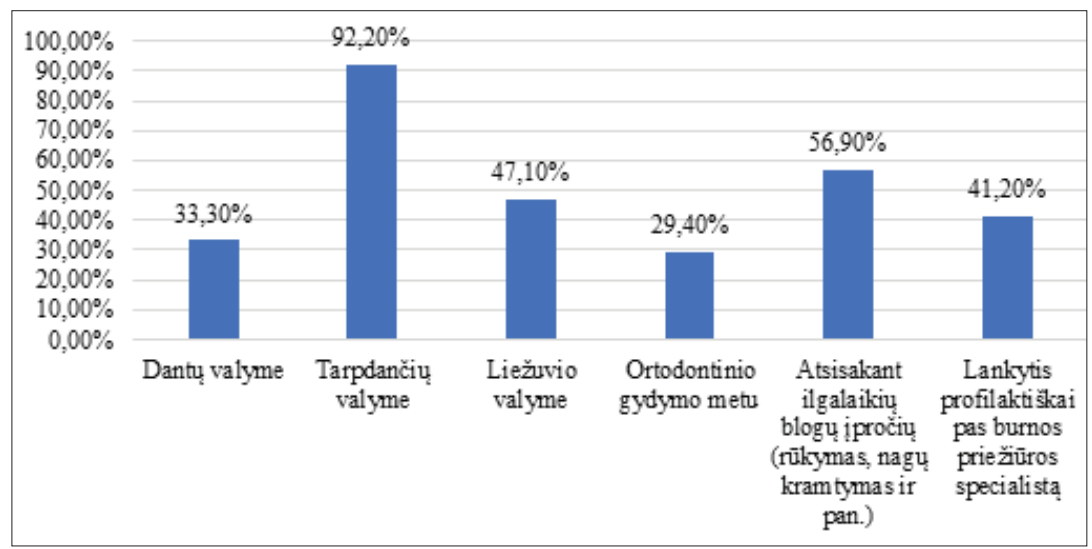

5 pav. Sritys, kuriose pacientams labiausiai trūksta motyvacijos, prižiūrint burnos ertmę $(\mathrm{N}=51)$.

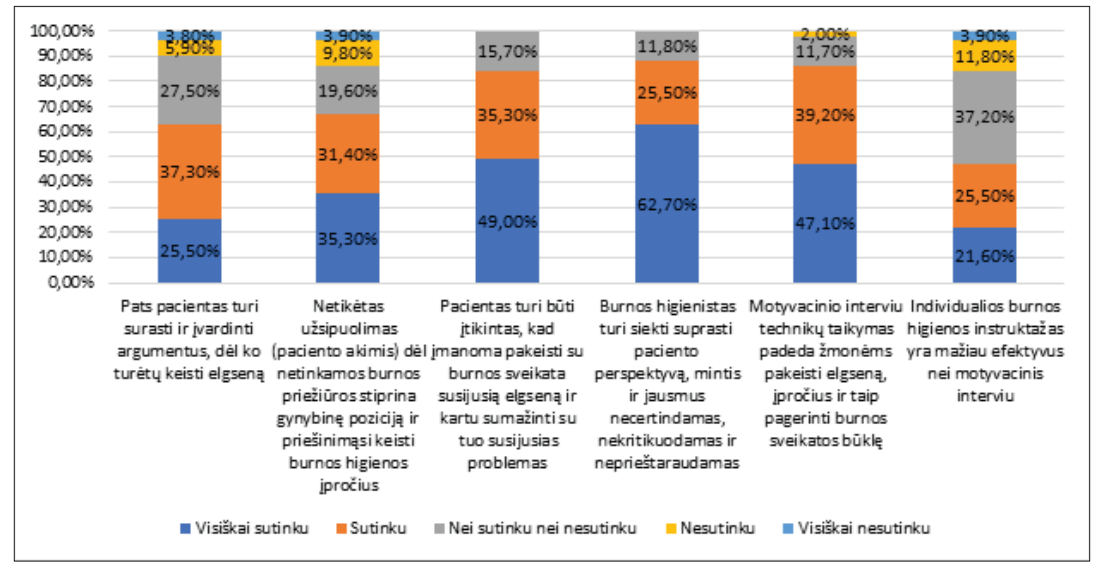

6 pav. Burnos higienistų požiūris ị motyvacinio interviu principų taikymą profesinèje veikloje $(\mathrm{N}=51)$. 
mus nevertindamas, nekritikuodamas, neprieštaraudamas. Trečdalis tyrime dalyvavusių burnos higienistų nurodè, jog jie nèra tikri, ar motyvacinis interviu yra efektyvesnis, nei burnos ertmès priežiūros instruktažas.

\section{Literatūra}

1. Bundy C. Changing behaviour: using motivational interviewing techniques. Journal of the Royal Society of Medicine 2004; 97(44): 43-47.

2. Cascaes AM, Bielemann RM, Clark VL, Barros AJ. Effectiveness of motivational interviewing at improving oral health: a systematic review. Rev Saude Publica 2014; 48(1):142-53. https://doi.org/10.1590/S0034-8910.2014048004616

3. Croffoot C, Bray KK, Black MA, Koerber A. Evaluating the effects of coaching to improve motivational interviewing skills of dental hygiene students. American Dental Hygienists' Association 2010;84(2):57-64.

4. Dogru A, Ovayolu N, Ovayolu O. The effect of motivational interview persons with diabetes on self-management and metabolic variables. J Pak Med Assoc 2019;69(3):294-300.

5. Frost H, Campbell P, Maxwell M, O'Carroll RE, Dombrowski SU, Williams B, et al. Effectiveness of motivational interviewing on adult behaviour change in health and social care settings: a systematic review of reviews. PLoS ONE 2018;13(10):e0204890.

https://doi.org/10.1371/journal.pone.0204890

6. Gillam DG, Yusuf H. Brief motivational interviewing in dental practice. Dentistry Journal 2019; 7(2):51.

https://doi.org/10.3390/dj7020051

7. Godard A, Dufour T, Jeanne S. Application of self-regulation theory and motivational interview for improving oral hygiene: a randomized controlled trial. Journal of Clinical Periodontology 2011; 38(12): 1099-1105. https://doi.org/10.1111/j.1600-051X.2011.01782.x

8. Kay EJ, Vascott D, Hocking A, Nield H. Motivational interviewing in general dental practice: A review of the evidence. $\mathrm{Br}$ Dent J 2016; 221(12):785-791. https://doi.org/10.1038/sj.bdj.2016.952

9. Kopp S, Ramseier C, Ratka-Kruger P, Woelber J. Motivational Interviewing As an Adjunct to Periodontal Therapy-A Systematic Review. Frontiers in Psychology 2017; 8:279. https://doi.org/10.3389/fpsyg.2017.00279

10. Soderlund PD. Effectiveness of motivational interviewing for improving physical activity self-management for adults with type 2 diabetes: A review. Chronic Illn 2018;14(1):54-68.

https://doi.org/10.1177/1742395317699449
11. Spaeth M, Bleich S, Hillemacher T. Motivierende Gesprächsführung bei Alkoholabhängigkeit [Motivational interviewing with alcohol-dependent patients]. Fortschr Neurol Psychiatr 2017; 85(9):549-565.

https://doi.org/10.1055/s-0043-115216

12. Wilder RS, Bray KS. Improving periodontal outcomes: merging clinical and behavioral science. Periodontology 2000 2016;71(1):65-81.

https://doi.org/10.1111/prd.12125

\section{THE ATTITUDE OF DENTAL HYGIENIST TOWARDS APPLICATION OF MOTIVATIONAL INTERVIEWING IN THEIR PRACTICE}

L. Bliūdžiūtè, R. Tamulienė, D. Mačiulienè

Keywords: dental hygienist, motivational interview.

Summary

The aim of this study was to reveal the attitude of dental hygienists towards application of motivational interviewing in their practice. Seventy-one dental hygienists took part in the research. Internet survey has been used for data selection. Descriptive statistics and group comparisons (Kruskal-Wallis test) statistics methods have been applied for data analysis. The results of the research have showed that the frequency of motivational interviewing with the patients doesn't differ between dental hygienists who work in private and governmental sector. The study results conveyed that dental hygienist, who have longer then 5 years work experience are using motivational interviewing more often than dental hygienist with the lower work experience. The state of patients' oral health and his/her knowledge about oral health related behaviour were the most important factors for deciding if the motivational interview should be applied to the patient. The results of the study showed, that, according to dental hygienist opinion, the most patients lack motivation in these areas: dental flossing, tongue brushing and maintaining dental routine check-ups. A significant number of survey participants highlighted the necessity of including motivational interview into dental routine check-up as well as specified that motivational interview serves as a preventive measure against chronic oral diseases. According to dental hygienists, a specialist has to be able to estimate the patient's perspective, mind-set and feelings without assessing, criticizing or opposing him/her. Moreover, the professional aims at persuading the patient to change improper dental care behaviour and consequently to reduce subject related problems.

Correspondence to: rasa.tamuliene@go.kauko.lt

Gauta 2021-10-07 